IJoLLT Vol. 2, No. 2 (September) 2019

eISSN: 2637-0484

\title{
On Language Corpora in the Translation Classroom
}

\author{
HELIA VAEZIAN \\ English Language Department \\ Khatam University \\ vaezian.helia@gmail.com
}

\begin{abstract}
The institutional training of translators is a relatively new phenomenon beginning in the mid-twentieth century in the West and even later in countries like Iran. Despite the rapid development of Translation Studies in the late twentieth century, translator education did not receive the attention it deserved with trainee translators being trained unsystematically, basically through trial and error. It was only during the recent years that translation scholars and teachers gradually started to address the issue in a more efficient way. The present paper aims to elaborate on the potential of using language corpora in translation classrooms as a means to better help the trainee translators acquire the skills and competencies they need to enter the professional translation market. It further explains the potential of corpora as a resource for translation teachers. Finally, the article proposes a method to archive students' translations in the form of a parallel corpus and further elaborates on the benefits of using the respective corpus.
\end{abstract}

Keywords: Language corpora, Translator training, Translation market, Translation teachers

Published online: 31 October 2019

To cite this article: Vaezian, H. (2019). On Language Corpora in the Translation Classroom. International Journal of Language, Literacy and Translation 2(2), 1-12. https://doi.org/10.36777/ijollt2019.2.2.020

To link to this article: https://doi.org/10.36777/ijollt2019.2.2.020 


\section{INTRODUCTION}

The institutional training of translators is a relatively new phenomenon beginning in the midtwentieth century with universities and institutions starting to offer translation programs distinct from language courses (Kelly, 2005). Until then translation courses were mostly offered to students enrolling in language programs, some of whom would eventually proceed as translators. As Kelly states, before the 20th century, translators were mostly -either language specialists or bilinguals self-taught in translation (p. 8).

Despite the rather short history of the institutionalized translator training, the future seems promising with researchers and practitioners within the discipline of Translation Studies starting to address the issue. Added to this is the increasing number of universities and institutions offering translation programs worldwide which implies that more attention would be directed towards translation programs and translator education. In Iran alone, there are more than nine postgraduate and two doctoral programs available to translation students.

Despite the rapid growth in the number of translation programs worldwide, there are serious concerns about the quality and content of the current translation programs. As stated by Pym, it is difficult "to find consensus on the fundamental questions of what should be taught, to whom, by whom and how" (2000, p. 209).

One of the major criticisms voiced against translator education has been its informal nature. As Baker (1998) states, translators have been trained informally for a long time, basically through trial and error. Student translators were given short texts to translate, the translations were discussed in great depth in class and finally the best translation was presented by the teacher to the class. This in fact can be regarded as a portrayal of a traditional translation class.

House (1980, cited in Kiraly, 1995, p. 7) describes the typical (traditional) translation class in the following words,

\footnotetext{
The teacher of the course, a native speaker of the target language, passes a text (the reason for the selection of this text is usually not explained, because it is often a literary essay that the teacher has just found by accident). This text is full of traps, which means the teachers do not set out to train students in the complex and difficult art of translation, but to ensnare them and lead them into error. The text is then presented, either orally or in written form for the following sessions and the whole group goes through the text sentence by sentence, with each sentence being read by a different student. The instructor asks for alternative translation solution, correct the suggested versions and finally present the sentence in its final correct form.
}

These unsystematic translation teaching practices stemmed from the belief that student translators can learn translation simply by translating over and over. As Kelly (2005, p. 11) has stated, this approach to translator education was "apedagogical, and of course extremely frustrating for students".

In response to this informal approach to training translators, some translation scholars proposed translator training based on the professional practice of translation (Nord, 1991). In line with this approach, scholars embarked on identifying the skills and competencies required to produce a translation and so the concept of translation competence came to the fore.

Translation competence has been defined by a number of scholars each presenting a different view of it. For Nord (1999), for instance, translation competence consists of metacompetence, text-production competence, text-analytical competence, and contrastive text 
competence, while Hatim and Mason (1997) present a traditional three-part translation competence inherited from linguistics, i.e. source text processing competence, transfer competence and target text processing competence.

The main problem with the translator training based on translation competence had to do with the fact that there was no consensus among translation scholars about the concept of translation competence itself. Moreover, the translation pedagogy based on the acquisition of translation competence was criticized by some scholars such as Toury (1984) who believed that the ability to translate is innate and gradually develops within bilinguals.

Some translation scholars further suggested that translation pedagogy should be based on translator competence rather than translation competence (Kiraly, 1995). Adopting this approach, the emphasis was placed on "the complex nature of the professional translator's task and the non-linguistic skills that are required of them" (p. 16). According to Kiraly (2003), the skills professional translators have and the work they do is far beyond the translation competence. He further asserted that what translators do is further than "the ability to create an equivalent target text in one language on the basis of pre-existing text written in another language" (p. 13). Koller (1992) shares the same view when he states,

The translator's competence surpasses pure foreign language competence as acquired in foreign language classes. The translator's competence, as the ability to produce a target language text for a source language text according to certain requirements, the so-called equivalent requirements, is qualitatively different from the mastery of the languages involved, thus different from pure language competence. (Cited in Rothe-Neves, 2007, p. 126)

There was, however, one major problem associated with translation pedagogy based on translator competence and that was defining the concept itself and agreeing on the skills and competencies professional translators needed to have (Rothe-Neves, 2007). The translation scholars and translation teachers thus had no choice other than continue their quest for finding a better approach to translator training. In the course of the following sections, two of the most recent approaches to translator training are discussed.

\section{THE SOCIAL CONSTRUCTIVIST APPROACH TO TRANSLATOR EDUCATION}

One of the interesting approaches to translator education is the social constructivist approach put forward by Kiraly (2000). Kiraly stresses the importance of translation teaching as "a dynamic, interactive process based on learners' empowerment; on emancipation of students from the domination of the teacher..." (p. 17-18). Referring to the drawbacks of teachercentered translation classrooms in providing trainees with the competencies they need to acquire as would be translators, Kiraly proposes an alternative pedagogy of translation which calls for collaborative learning and learning through experience (p.18).

Kiraly believes that a conventional teacher-centered translation class is not "an ideal venue for the development of a professional self-concept" and cannot provide trainees with the opportunity to learn how "to work collaboratively with other professionals" (p. 15). Instead, he recommends a translation class in which the teacher acts as a guide and facilitator assisting the students in their journey to move from novices to professional translators. He further emphasizes the importance of group learning and "shifting the focus of attention in the 
classroom away from the one-way distribution of knowledge in the traditional classroom, toward multi-faceted, multi-directional interaction between various participants in the classroom situation" (p. 20).

The core of the social constructivist approach, as put forward by Kiraly (2000), is that the trainee translators would learn how to move towards professionalism through experience and interaction. In contrast to the transmissionist view of learning, the social constructivist approach considers learning as an active process with learners having their hands-on experience. It further stresses that the learners can learn by creating their own meaning and understanding, instead of memorizing or taking on others' conceptions of understanding. It is thus based on the view that the knowledge cannot be simply transferred from the teacher to the students.

In sum, the social constructivist approach to translator education asks for collaborative translation classrooms with learners actively involved in the learning process. This approach with its cooperative focus seems to be in line with the recent approaches to education in general which put emphasis on learner autonomy and cooperative learning.

\section{THE PROFESSIONAL APPROACH TO TRANSLATOR TRAINING}

There is yet a more recent approach to translator training which focuses on translation market. In this approach, the emphasis is placed on the translation market and its idiosyncrasies. As OlveraLobo, Castro-Prieto et al. (2005, p. 138) state, "the main goal of the Professional Approach to Translator Training is to introduce translation students to the professional market and help them get acquainted with working conditions in the real labor market by means of a simulated translation agency". They further argue that analyzing the characteristics of the market and the current training conditions would help translation teachers see the existing shortcomings in translation syllabi (2005).

Pym too stresses the necessity of taking the market demands into account in designing translation programs (1993). According to Pym, "we should be teaching translation as a general set of skills that our students can apply and adapt to the changing demands of future markets, and indeed to changing professions" (p. 116).

The starting point in this approach is knowing the translation market and its idiosyncrasies and further helping the student translators move towards acquiring the skills expected from them in the market. There is however one point that must be acknowledged when it comes to translation market. The current translation market like many other markets is fluid in the sense that it is constantly changing. One of the implications of this situation is that the requirements of the market and so what is expected from translators are subject to change. It thus would not be easy to agree on the exact skills and competencies required of translators in the market.

What translation curriculum designers and teachers can do in this situation is to introduce the students to the basic skills required of translators in the market and then teach them how to develop their skills based on the market demands. By adopting this approach, translation teachers should try to equip trainees with the skills transferable to various situations the students may encounter in future. The present paper adopting such a market-based approach to translator education elaborates on the benefits of incorporating corpora into translation classrooms. 


\section{THE PRESENT TRANSLATION MARKET}

If we accept that the mere objective of the translator education is guiding students towards becoming professional translators and helping them acquire the skills and competencies they need to be able to work in today's translation market, it is quite reasonable to first consider the competences required of the professional translators in the present translation market before going on any further into our discussion of teaching translation.

There is no doubt that the translation market has changed considerably during recent years. The advent of the Internet along with machine translations and translation memories all have had their own effects on translation practice and translation market. Nowadays, a large number of translation jobs are sent via emails to freelance translators across the world; Clients post their jobs on translation portals such as Proz and Translators Cafe and freelance translators all over the world can quote and get the jobs.

This new globalized translation market has had an indirect effect on the skills and competencies required of translators. To enter this market, translators need to be familiar with the state of the art translation technology. A large number of jobs posted on Proz, for example, require translators to use SDL Trados, DejaVu or other translation soft wares. Moreover, translators are required not only to work with translation memories, but also to deliver the final translation in the format the client may ask for. This situation implies that the range of the skills required of translators has definitely expanded far beyond simple text production skills. As Olvera-Lobo, Castro-Prieto et al. (2005, p. 132) state,

\footnotetext{
The demanding professional translation market expects would be professionals to have a broad knowledge of the subject matter of the text, to use a large number of computer tools proficiently, and to be versatile in the sense that they can master all elements in the translation process.
}

The demanding professional translation market expects would be professionals to have a broad knowledge of the subject matter of the text, to use a large number of computer tools proficiently, and to be versatile in the sense that they can master all elements in the translation process.

To succeed in the present competitive translation market, translators need to expand both their linguistic and extra linguistic knowledge and skills. Among other things, they need interpersonal skills to get the jobs and maintain a good relation with their clients and fellow translators; they need computer skills to work with translation software, translation memories and corpora; they need editing skills to provide their clients with an acceptable final version and finally they need encyclopedic knowledge of various subject fields to work on various texts or else have the necessary resources to acquire such knowledge as the need arises (Vaezian, 2009).

The present translation market is also marked by its tight deadlines which implies that translators may seldom have the luxury of time to spend hours searching for the right resources (dictionaries, subject matter experts, books, ...) to help them with the (technical) projects at hand. According to Olvera-Lobo, Castro-Prieto et al. (2005, p. 135), "The (new) translation market sets increasingly unrealistic and short deadlines and delivery dates, and the daily volume of translation is growing at an incredible rate". 
Another prominent feature of the current translation market is that many professional translators today work on various text types and genres. According to Pym (1993), the specialization in the translation market requires translators to be ready to deal with translation of various specialized texts rather than focusing on translation of just one or two genres and text types. He further states that in the specialized translation market, having flexibility to adapt to translation of various specialized texts is more important than having in-depth knowledge in one particular field (1993).

Ulrych $(2005$, p. 22) shares the same view when she states "the idea that professional translators work predominantly in one or two specialist fields is in fact swiftly losing grounds as the need for translation expands exponentially in volume and variety". For freelance translators, for example, limiting their specialized fields to two or three fields may limit their chances of getting more translation jobs. In other words, the more specialized fields translators can translate, the better chances they have in the market. Considering the idiosyncrasies of the present translation market explained above, in the course of the following section we elaborate on what language corpora have to offer in translation classrooms.

\section{WHAT DO LANGUAGE CORPORA HAVE TO OFFER?}

Language corpora first entered the disciple of Translation Studies in 1990s as a means to study the language of translation (Baker, 1993) and they sparked a large body of research into translational features in various languages. Laviosa, for instance, used a comparable corpus of English narrative prose to study the differences between translational and non-translational English (Laviosa, 1998). Over the course of the following years, language corpora gradually found their way into other areas in Translation Studies including translation teaching.

Bernardini (1997) is arguably the first translation scholar who asked for the incorporation of language corpora into translation classrooms. Bernardini suggested that traditional translation teaching should be complemented with large corpora concordancing to let the students acquire the skills they need to become (professional) translators. According to her, "educating learners to use comparable corpora as reference tools in their everyday language may result in a betterdocumented, more accurate, as well as more fluent translations" (2004, p. 20). Bernardini (2015) further talks about the introduction of a course on corpus use for translators outside the translation classroom in order to help translation students get to know the potential of language corpora in the context of translation. Zanettin (1998) too referring to the considerable benefits of corpora for trainee translators puts forward the idea of Translator Trainee Workstations which asks for the integration of translation activities based on corpora into translation curriculum. According to Zanettin, "a translator trainee workstation comprising a word processor, bilingual corpora and facilities for bilingual concordancing together with other resources may constitute a valuable aid in the training of translators" (p. 626).

Since then, there have been a large number of studies on the applications of different types of corpora in translation classrooms. Corpora, among other things, were shown to enhance the learners' source text understanding (Bowker, 1998), their understanding of specialized terms (Gavioli and Zanettin, 1997), and their knowledge of different text types (López-Rodríguez and Tercedor-Sánchez, 2008), and they proved useful in providing the student translators with unpredictable and incidental learning (Aston, 1999; Zanettin, 2001) and helping them in 
identifying discourse-based features (Kubler, 2015). They were also shown to enhance students' confidence (Varantola, 2003; Monzo, 2003) and autonomy (Bowker, 2003).

Vaezian $(2018$, p. 62$)$ adopting a different approach to the use of corpora for translation purposes asserts that "accessing ready-made corpora may not be always easy. This is especially true for less dominant languages such as Persian for which the number of available corpora is very limited". She further continues, "moreover, most existing corpora are domain specific which implies that they supply a limited range of genres and text types. They, thus, may not always contain the information the translator is looking for" (p. 62). Vaezian further introduces the concept of the Web as a corpus and studies the potentials of using it in an undergraduate translation class. Her subjects drawing on the information extracted from the Web using Google were able to make a decision on choosing one equivalence over another through observing meaningful differences in the contexts of the terms/phrases in question (2018).

As the body of literature reviewed above proves corpora have a lot to offer in the context of translation classrooms. Now let us discuss the benefits of using corpora in the translation classroom in light of the present translation market. As noted before, the present translation market is marked by its tight deadlines and increasing "specialization" which require translators to be ready to work on translation of various specialized texts under tight deadlines. Under this circumstance, using specialized corpora - especially for highly specialized texts for which there may be no dictionaries/glossaries available- seems like a good option.

Specialized corpora which contain specialized texts can potentially help the translators learn about the specialized text type under question including its terminology, register and style. As observed by Bowker (1998, p. 648), the use of specialized native-language corpora improved the quality of translation in terms of "correct term choice, and idiomatic expression". Moreover, specialized corpora proved useful in helping the translators understand the main concepts of a specialist subject field and get familiar with the phraseology of the field (LópezRodríguez and Tercedor-Sánchezc, 2008). They can also provide translators with information related to forms and meanings of the specialized type of text in question including terminology, features of register and text structure (Aston, 1999). As Bermúdez Bausela (2016, p. 372) states,

There is a number of ways in which specialized corpora can help the translator. We can generate word lists to identify the field and level of specialization of the ST. We can use them to learn about the subject we are translating, and about the most common lexical and grammatical patterns through the retrieval of concordances, collocates and clusters.

In sum, specialized corpora can potentially help the translators gain a better understating of the specialist field under study by providing them with conceptual and terminological information. They thus may be useful in contexts where available resources come in short in providing necessary information or when there is no available resource to resort to. This may be particularly relevant when a translator is given a translation on an unfamiliar subject which needs to be delivered by a tight deadline and for which there are no dictionaries and glossaries available. In this scenario using a specialized corpus -be it a ready-made corpus, a DIY corpus or WWW- may be a good option to get familiar with the unfamiliar. If we accept that once we learn how to use corpora to extract translationally-relevant information, we are in fact equipped with the basic potential skills to venture into translation of various (specialized) texts, then we 
can rightly claim that teaching the student translators about corpora and their potentials as a translation resource seems as necessary as teaching them about using dictionaries.

\section{CORPORA AS A RESOURCE FOR TRANSLATION TEACHERS}

Language corpora can be used by translation teachers to create teaching and testing materials. Parallel or translation corpora which contain source texts and their translations are one of the most useful corpus types in this context. Translation teachers can use the source component of parallel corpora to derive translation assignments for the students and they can further use the target component to compare the students' productions with the work of professional translators to better understand the students' weak points and problems. The translations in the target component of parallel corpus can also be presented to the class. This would help the students compare their own translations with the works of professional translators and see how professional translators translate and what strategies they draw on in dealing with translation problems (Cappelle et al. 2016, Pearson, 2003). Such information can further help the students draw their own models of translation. This is in line with Baker's view on applications of parallel corpora in translation, which asks for drawing on parallel corpora to "provide realistic models for trainee translators" (1995, p. 231).

Moreover, corpora can be used by translation teachers to justify their evaluation of students' translations and their proposed translation strategy. Drawing on corpus data, translation teachers can explain their own translation solutions and later on provide hard evidence from corpora to convince (difficult) students. Last but not least, corpora of specialized texts can be used by translation teachers to confirm their intuitions as for the correct terminology, collocations and syntactic structures in certain texts types (Pearson, 2003).

\section{ARCHIVING STUDENTS' TRANSLATIONS}

Translation teachers constantly collect and correct the translations done by students. These translations, if collected, can form a valuable source of information for teachers over time (Tengku Mahadi, Vaezian, \& Akbari, 2010). A corpus of translation produced by students for a given source text, for instance, can be used to identify common errors in the students' translations.

To build a corpus of translation produced by the students for a given source text, the very first step is asking students to submit the electronic copies of their translations. During the next step, the teacher can use the freely-available online tools such as LF Aligner to create a parallel corpus including the source texts and all the translations delivered by the students. LF Aligner is a freeware created to help translators create translation memories from the source texts and their translations and it automatically does the aligning processes at either the sentence or the paragraph levels. Based on the author's experience with this tool, the auto alignment at sentence the level for English $<>$ Persian translations does not work very well. This is while the alignment is quite acceptable at the paragraph level. The following image is a snapshot of LF Aligner graphic editor for an English text on "Social democracy" and three Persian translations produced by the student translators auto aligned at paragraph level. It is necessary to mention 
that LF Aligner allows users to review and edit the pairings either in its graphical user interface or in an xls file and the Output can be in one of the followings: tab delimited txt, TMX and xls.

\begin{tabular}{|c|c|c|c|c|c|}
\hline 1 & Social Democracy & 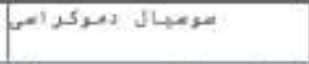 & 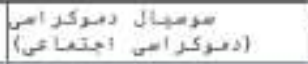 & 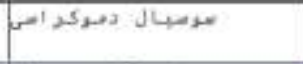 & 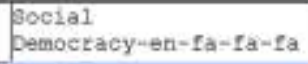 \\
\hline 2 & 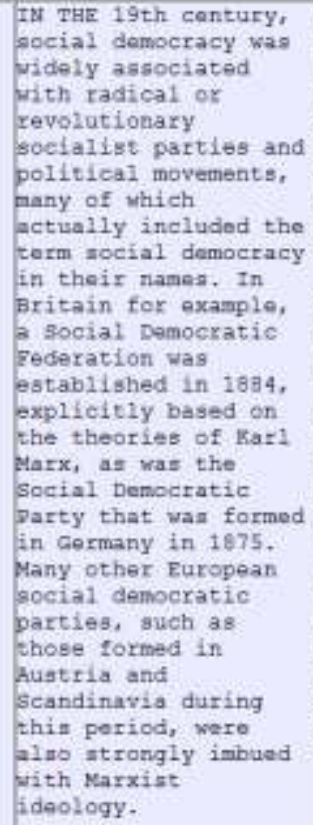 & 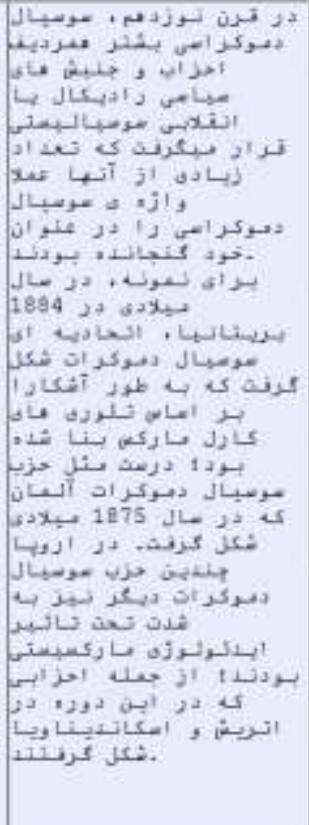 & 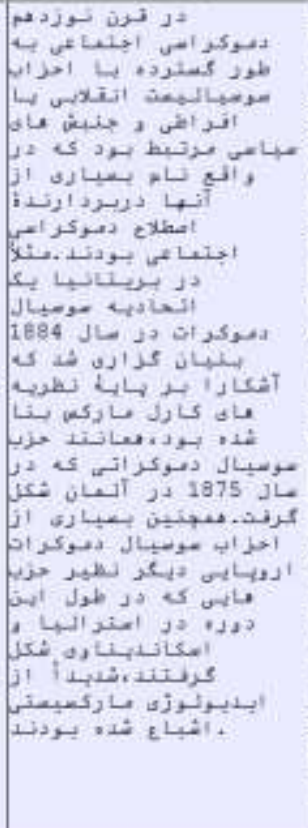 & 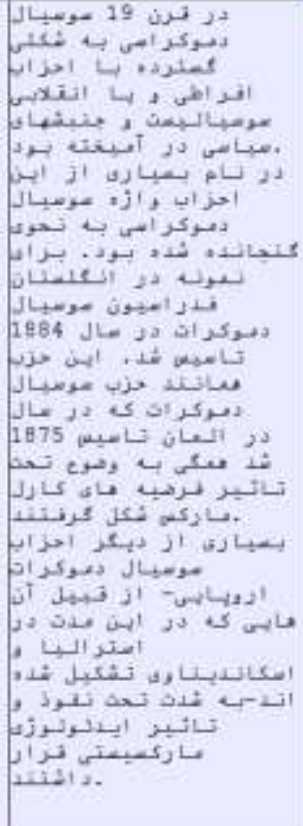 & $\begin{array}{l}\text { Bocial } \\
\text { Pomocracy-en-fa-fa-fad }\end{array}$ \\
\hline
\end{tabular}

Figure 1: LF Aligner graphic editor showing an English text on "Social democracy" and three Persian translations of it.

Translation teachers can use such aligned parallel corpora of the students' translations for a variety of purposes. For instance, such corpora can help the teachers identify the areas which are more difficult for the students as a whole as opposed to the areas which seem tricky for only a few students. They can also use such corpora to study the various strategies used by the students to deal with specific translation problems. Such corpora can also provide teachers with an overall picture of the students' translation skills and their patterns of language use. Adopting a different approach, such corpora can come in handy while rating students' translations. They can help translation teachers assess the students' translations and judge the severity of their errors concurrently.

Such aligned corpora can also be presented to the class. This allows students assess their own translations in the light of the translations produced by their peers. Students can further discuss various translation strategies adopted and receive feedback from their teachers as well as their peers. It also allows students to explore variation and choice in translation. Moreover, these corpora can be used to sensitize students to the common errors in their translations.

\section{FINAL WORDS}

There is no doubt that language corpora are useful tools when it comes to translation. They are valuable sources of linguistic information which can be used alongside other translation 
resources for a variety of purposes, from extracting conceptual information to learning about the common collocates in the target language and acquiring information on the contexts of words/phrases in question. Yet, despite the apparent benefits of language corpora, they seem a bit neglected in translation classes. There seems to exist a number of reasons behind this situation. First, as highlighted by Kubler et al. (2015), existing experimental research on the usefulness of corpora is poorly documented. Second, some "translation teachers seem reluctant to make a change in how they have run their classes for years" (Tengku Mahadi, Vaezian, \& Akbari, 2010, p. 122). Hence, some of them may not be using language corpora in their classes. This implies that the students may not learn about the potential of corpora, let alone master working with corpora. Third, "some students do not seem receptive to corpus-based translation classes. They may either lack the computer skills needed to work with corpora or fear the burden of responsibility they would have in such classes." (p. 122). This is partly due to the fact that "the students' learning experience in corpus-based translation classes would be quite different from what they have experienced in traditional translation classes" (p. 122).

This situation implies that if we want to see professional and student translators start using corpora we have to invest in providing empirical data on the uses of language corpora in translation on the one hand and introduce corpora into our translation classes and train students on how to work with them on the other hand. Solid empirical data can convince professional translators to start using corpora while running corpus-based translation classes guarantees that our students are aware of the potential of corpora and know how to extract translationallyrelevant information from them.

\section{REFERENCES}

Aston, G. (1999). Corpus use and learning to translate. Textus, (12), 289-314.

Baker, M. (1993). Corpus Linguistics and Translation Studies: Implications and Applications. In M. Baker, G. Francis and E. Tognini-Bonelli (Eds.) Text and Technology: In honor of John Sinclair (pp. 233-250). Amsterdam and Philadelphia: John Benjamins. https://doi.org/10.1075/z.64.15bak

Baker, M. (1995). Corpora in Translation Studies: an overview and some suggestions for future research. Target, 7 (2), 223-243. https://doi.org/10.1075/target.7.2.03bak

Baker, M. (Ed.) (1998). Encyclopedia of Translation Studies. London-New York: Routledge. https://doi.org/10.4324/9780203359792_A

Bermúdez Bausela, M. (2016). The importance of corpora in translation studies: a practical case. In A. Pareja-Lora, C. Calle-Martínez, \& P. Rodríguez-Arancón (Eds), New perspectives on teaching and working with languages in the digital era (pp. 363-374). Dublin: Research-publishing.net. https://doi.org/10.14705/rpnet.2016.tislid2014.448

Bernardini, S. (1997). A Trainee Translator 's Perspective on Corpora. Corpus use and learning to translate, 14-15 November 1997, Bertinoro. Retrieved from http://www.sslmit.unibo.it/introduz.htm.

Bernardini, S. (2015). Exploratory learning in the translation/language classroom: Corpora as learning aids. CULT Conference, 26-29 May, Alicante, 2015.

Bowker, L. (1998). Using specialized monolingual native language corpora as a translation resource: A pilot study. Meta, 43 (4), 631-651. https://doi.org/10.7202/002134ar 
Bowker, L. (2003). Towards a Collaborative Approach to Corpus Building in the Translation Classroom. In B.J. Baer and G. Koby (Eds.), Beyond the Ivory Tower: Rethinking Translation Pedagogy (pp. 193-210). Amsterdam and Philadelphia: John Benjamins. https://doi.org/10.1075/ata.xii.14bow

Cappelle, B., Clercq O., Sutter, G., Loock, R., Plevoets, K. (2016). A corpus-based, statistical approach to translation quality. Journée d'études Traduction \& Qualité. Corpus et qualité: Université.

Gavioli, L. \& Zanettin, F. (1997). Comparable corpora and translation: a pedagogic perspective. Paper presented at the first international conference on Corpus Use and Learning to Translate. Bertinoro, 14-15 November 1997.

Hatim, B. \& Mason, I. (1997). The Translator as Communicator. London \& New York: Routledge.

Kelly, D. (2005). A Handbook for Translator Trainers, Translation Practices Explained Series. Manchester: St. Jerome Publishers.

Kiraly, D.C. (2000). A Social Constructivist Approach to Translator Education: Empowerment from Theory to Practice. Manchester: St. Jerome.

Kiraly, D.C. (1995). Pathways to Translation, Pedagogy and Process. Kent and London: The Kent State University Press.

Kiraly, D.C. (2003). From Instruction to Collaborative Construction: A passing fad or the promise of a paradigm shift in translator education? In B.J. Baer and G.S. Koby (Eds.) Beyond the Ivory Tower: Rethinking translation pedagogy (pp. 3-27). American Translators Association Scholarly Monograph Series, Vol. XII. Amsterdam and Philadelphia: John Benjamins. https://doi.org/10.1075/ata.xii.03kir

Kubler, N., Pecman, M., \& Volanschi-Mestivier, A. (2015). A study on the efficiency of corpus use for translation students during terminology processing and LSP translation. CULT Conference, 26-29 May, Alicante, 2015

Laviosa, S. (1998). Core Patterns of Lexical Use in a Comparable Corpus of English Narrative Prose. Meta, 43(4), 557-570. https://doi.org/10.7202/003425ar

López-Rodríguez, C.I. and Tercedor-Sánchez, M.I. (2008). Corpora and Students 'Autonomy in Scientific and Technical Translation Training. The Journal of Specialized Translation, (9), 2-19.

Monzo, E. (2003). Corpus-based Teaching: The Use of Original and Translated Texts in the training of legal translators. Translation Journal, 7(4). Retrieved from http://accurapid.com/journal/26edu.htm

Nord, Ch. (1991). Text Analysis in Translation: Theory, Methodology and Didactic Application of a Model for Translation-oriented Text Analysis. Amsterdam: Rodopi.

Nord, Ch. (1999). Translating as a Text Production Activity. University of Applied Sciences, Magdeburg, Germany. Retrieved from http://www.fut.es/ apym/symp/nord.html

Olvera-Lobo, M., Castro-Prieto, M., Quero-Gervilla, E., et al. (2005). Translator training and modern market demands. Perspectives: Studies in Translatology, 13(2), 132-142. https://doi.org/10.1080/09076760508668982

Pearson, J. (2003). Using Parallel Texts in the Translator Training Environment. In F. Zanettin, S. Bernardini \& D. Stewart (Eds.) Corpora in Translator Education (pp. 15-24). Manchester: St Jerome Publishing.

Pym, A. (1993). On the Market as a Factor in the Training of Translators. Koiné, 3, 109-121. 
Pym, A. (2000). Innovation in Translator and Interpreter Training. Report on an on-line symposium. Across Languages and Cultures, 1(2), 209-211. https://doi.org/10.1556/Acr.1.2000.2.5

Rothe-Neves, R. (2007). Notes on the concept of translator's competence. Quaderns, (14), 125138

Tengku Mahadi, T. S., Vaezian, H., \& Akbari, M. (2010). Corpora in translation: A practical guide. Bern: Peter Lang. https://doi.org/10.3726/978-3-0351-0108-9

Toury, G. (1984). The Notion of Native Translator and Translation Teaching. In W. Wilss and G. Thome (Eds.) Die Theorie des Übersetzens und ihr Aufschlusswert für dir Übersetzungs- und Dolmetschdidaktik (pp. 186-195). Tübingen: Narr.

Ulrych, M. (2005). Training Translator: Programs, curricula, practices. In M. Tennent (Ed.) Training for the New Millennium. Amsterdam and Philadelphia: John Benjamin. https://doi.org/10.1075/btl.60.06ulr

Vaezian, H. (2009). Corpora in Translation Classrooms. In H. Che Omar, H. Haroon and A. Abd. Ghani (Eds.) The Sustainability of the Translation Field: The 12th International Conference on Translation (pp. 242-249). Kula Lumpur: Malaysian Translators Association.

Vaezian, H. (2018). The web as a corpus: a resource for translation. Vertimo studijos 11(11), 6275. https://doi.org/10.15388/VertStud.2018.5

Varantola, K. (2003). Translators and Disposable corpora. In F. Zanettin, S. Bernardini and D. Stewart (Eds.) Corpora in Translator Education (pp. 55-70.). Manchester: St Jerome Publishing.

Zanettin, F. (1998). Bilingual comparable corpora and the training of translators. Meta, 43(4), 616-630. https://doi.org/10.7202/004638ar

Zanettin, F. (2001). Swimming in words: corpora, language learning and translation. In Aston, Guy (Ed.) Learning with corpora (pp. 177-197), Houston, Texas: Athelstan. 